\title{
Ocins for Food Safety
}

\author{
Shilja Choyam ${ }^{1,2}$, Alok Kumar Srivastava ${ }^{3}$, Jae-Ho Shin ${ }^{4}$ and Rajagopal Kammara',2* \\ 'Affiliated to AcSIR for Ph.D. Thesis, CSIR-CFTRI, Mysuru, India, ${ }^{2}$ Department of Protein Chemistry and Technology, \\ CSIR-CFTRI, Mysuru, India, ${ }^{3}$ Food Safety \& Analytical Quality Control Laboratory, CSIR-CFTRI, Mysuru, India, \\ ${ }^{4}$ School of Applied Biosciences, Kyungpook National University, Daegu, South Korea
}

\section{OPEN ACCESS}

Edited by:

Javier Carballo,

University of Vigo, Spain

Reviewed by:

Pascal Degraeve,

Claude Bernard Université Lyon 1,

France

Fohad Mabood Husain,

King Saud University, Saudi Arabia

*Correspondence:

Rajagopal Kammara

krgopal22@rediffmail.com;

rajagopalk@cftri.res.in

Specialty section:

This article was submitted to

Food Microbiology,

a section of the journal

Frontiers in Microbiology

Received: 18 March 2019

Accepted: 15 July 2019

Published: 02 August 2019

Citation

Choyam S, Srivastava AK, Shin J-H and Kammara R (2019)

Ocins for Food Safety.

Front. Microbiol. 10:1736.

doi: 10.3389/fmicb.2019.01736
The food industry produces highly perishable products. Food spoilage represents a severe problem for food manufacturers. Therefore, it is important to identify effective preservation solutions to prevent food spoilage. Ocins (e.g., bacteriocins, lactocins, and enterocins) are antibacterial proteins synthesized by bacteria that destroy or suppress the growth of related or unrelated bacterial strains. Ocins represent a promising strategy for food preservation, because of their antagonist effects toward food spoilage microorganisms, high potency, and low toxicity. Additionally, they can be bioengineered. The most common and commercially available ocins are nisin, plantaracin, sakacin $\mathrm{P}$, and pediocin. Several ocins have been characterized and studied biochemically and genetically; however, their structure-function relationship, biosynthesis, and mechanism of action are not understood. This narrative review focuses primarily on ocins and their relevance to the food industry to help prevent food spoilage. In particular, the applications and limitations of ocins in the food industry are highlighted.

Keywords: bacteriocin, antagonism, biopreservation, dairy, meat, fruits, vegetables

\section{INTRODUCTION}

In humans, nutritional $\Lambda$ requirements are met by different food groups, e.g., dairy products, fruits, vegetables and legumes, meats, and grains, which are perishable and susceptible to microbial spoilage. Spoilage is characterized by changes in food quality that impact food appearance, color, texture, and/or flavor. Foods have a distinct and characteristic microflora from production to storage. Numerous microorganisms isolated from foods are capable of producing spoilage metabolites when unlimited growth is permitted (Gram, 1989). Food spoilage and waste represent an economic burden that cannot be controlled in spite of modern food technologies and preservation techniques. The typical microflora that develop during food storage have been extensively reviewed (Mossel et al., 1995). The main challenge is to ascertain the relationship between microbial colonies and microbial metabolites, the results of which would assist in the analysis and possible prediction of microbial spoilage (Borch and Agerhem, 1992; Drosinos and Board, 1995).

A vast number of spoilage microorganisms contribute to the deterioration of foods. However, the time between the appearance of large bacterial populations and the occurrence of spoilage events may vary depending on the food, intrinsic and extrinsic variables, and the growth characteristics of specific spoilage microorganisms (SSO). Therefore, identifying SSO and understanding the interactions between SSO and other microorganisms or their metabolites (i.e., synergism/antagonism) 
are important for estimating the potential damaging effects. Ultimately, microbial spoilage and the resulting (bio)chemical decomposition of foods should be evaluated.

Ocins are antimicrobial peptides or proteins produced by bacterial species and strains (Jack et al., 1995). Currently, ocins are used to control microbial growth in a wide variety of foods and beverages. Therefore, ocins have considerable commercial benefits. Even though thousands of ocins exist, most do not have appreciable activity essential for commercialization. The application of ocins in the food industry includes ex situ and in situ production by ocinogenic strains. The major obstacles of ocin use in the food industry are establishing large-scale production methods and implementing pilot and industry level applications. A standard method is the preparation of incompletely purified ocin concentrates as lyophilized powders. For example, nisin, which is produced by Lactococcus lactis fermentation of milk-based substrates and pediocin PA-1/AcH (pediocin PA-1) from Pediococcus acidilactici, which is commercialized as ALTA 2341 and used as a food protectant (Rodríguez et al., 2002). Even though nisin is extensively used in the food industry, it has a few limitations, including poor stability at high temperatures (Holcapkova et al., 2017), susceptibility to physiological enzymes (e.g., proteinase $\mathrm{K}$, trypsin, and chymotrypsin), and effective activity at a very narrow $\mathrm{pH}$ range. Therefore, it is important to develop novel protein-based antimicrobials for applications in the food industry. Chikindas et al. (1995) reported the applications of bacteriocins, and Yang et al. (2014) discussed the antimicrobial activities of bacteriocins and their applications in foods and pharmaceuticals. The authors argued that several purified bacteriocins have been used in the food industry to extend food preservation time and treat certain diseases. Bacteriocins play significant roles in ecological homeostasis wherein they maintain the population dynamics within the species (Margaret and David, 1999). This function has been exploited for human betterment. Even though there are few review articles focused on bacteriocin databases, there are no studies on the enhanced production of recombinant bacteriocins. Consequently, we are unparalleled in this respect.

\section{BACTERIOCINS AND BIOFILMS}

Biofilms represent a microbial defense mechanism against antimicrobials. Pathogenic and infectious microorganisms such as methicillin-resistant Staphylococcus aureus (MRSA), Pseudomonas aeruginosa, Gardnerella vaginalis, Staphylococcus epidermidis, and Streptococcus mutans have the capacity to form biofilms. Referable to the lack of efficient, rapid and effectively penetratable antibiotics and also the drug resistance to biofilm formation made the pathogen removal not just hard but also impossible to wipe out completely. Small molecular weight bacteriocins represent a viable solution. Due to their low molecular weight, these bacteriocins have the ability to rapidly diffuse through biofilms and inhibit their formation. In the healthcare industry, biofilms represent a significant problem. Once the biofilm is formed in healthcare devices or instruments, the amount of antibiotic required for the eradication of the biofilm increases from 100 to $1,000 \times$. Biofilm formation begins with the adherence of bacteria to a substrate, followed by maturation of the biofilm and subsequent release of clusters of cells from the matrix of the biofilm (Garrett et al., 2008; Flemming and Wingender, 2010).

It is challenging to dislodge mature biofilms; therefore, researchers have been evaluating ways to target the initial phases of biofilm formation (Dosler and Karaaslan, 2014). Unfortunately, the results have not been satisfactory. The current treatment consists on using antibiotics, antimicrobials, essential oils, and quorum sensing inhibitors. Nanoparticles may play an effective role as biofilm inhibitors (Algburi et al., 2017). Bacteriocins that have been used in the suppression of biofilm formation or growth include nisin, nukacin (Sashihara et al., 2000; Okuda et al., 2013; Chopra et al., 2015; Duarte et al., 2017), lacticin Q, sonorensin, and hyicin 4244. Nisin, which has a rapid penetration capacity and effective permeating activity, is an effective antibiofilm agent that can be bioengineered. Bioengineered or mutated forms of nisin have enhanced stable diffusibility (Davison et al., 2010; Field et al., 2015a,b,c).

The use of ocins in the food industry depends on their antimicrobial spectrum and the feasibility to introduce them directly into the food as a powder or indirectly via the inoculation of the food with an ocin-producing strain (Michael et al., 2018). Finally, functional aspects will be known by the use of the fermented product that has been produced in the presence of lactic acid bacteria. The antimicrobial activity of ocins may be estimated by disk diffusion, Well diffusion and also Unique well diffusion assay (Holder and Boyce, 1994; Kimara et al., 1998; Shilja et al., 2015). Both tests are highly dependent on the diffusion of ocins. Therefore, lack of diffusion may produce misleading results. The standard method for measuring ocin antimicrobial activity (Shilja et al., 2015) relies on a novel wellbased assay that does not depend entirely on the diffusion of ocins. Several studies on the application of ocins in foods have been conducted. While most studies have focused on the use of ocins in the preservation of meat and dairy products, ocins may have potential in other food items, such as fruits and vegetables.

\section{MECHANISM AND ACTION OF NISIN. WHY IS NISIN PREFERRED?}

Nisin production requires low cost ingredients; however, selling costs rapidly increase with commercially available bacterial ingredients.

\section{SOCIAL ACCEPTANCE}

Currently, Nisin is not considered to be a market constraint in Europe or United States. Once acceptance has no issue in developed countries that do not cause product failure around the globe. Nisin has been extensively used for food safety and stability. The use of nisin represents a non-chemical, nontransforming approach that does not affect flavor, texture, or product structure. 


\section{NISIN MECHANISM AND ACTION}

There are different types of nisin molecules, e.g., nisin A, nisin $\mathrm{Q}$, and nisin $\mathrm{Z}$. These molecules mainly differ in their amino acid sequence; however, they possess similar antimicrobial action. Nisin Z, which is present as a monomer and dimer, has higher diffusibility compared with nisin A. Nisin A is a class I antimicrobial protein that displays a unique pore-forming activity. The pore forming activity is rapidly enhanced in the presence of a lipid II moiety (Breukink et al., 1999; Wiedemann et al., 2001). Nisin binds to the lipid II moiety through the $\mathrm{N}$-terminus of two lanthionine rings, leading to the formation of a pyrophosphate cage around the head-group of lipid II (Van Heusden et al., 2002; Hsu et al., 2004; Wiedemann et al., 2004). Additionally, nisin inhibits cell wall biosynthesis by inhibiting PG synthesis. Segregation and loss of the lipid II moiety is another bactericidal mechanism of nisin. Research on nisin began in 2003 by Okeley, who characterized the components of the nisin biosynthetic pathway (Okeley et al., 2003). A few studies were performed during the 19th century. During the process of understanding its mechanism of action, several secondary nisin derivatives have been isolated. Nisin $\mathrm{O}$ was discovered by Hatziioanou et al. (2017). Thurusin CD is an ocin isolated from Bacillus thuringiensis. The mechanistic aspects of ocins clearly envisage that nisin and common antibiotics, such as vancomycin and metronidazole, have comparable activity (Rea et al., 2010).

\section{ADVANTAGES OF THE REVIEW PAPER 'OCINS FOR FOOD SAFETY' OVER OTHER REVIEWS}

The present manuscript comprehensively reviews the application of bacteriocins from all sources for the inhibition or elimination of food spoilage microbes for food safety. For easier understanding, the food sector was categorized, and applications of bacteriocins were mentioned separately. The successful application of native and recombinant bacteriocins against the food spoilage microbes was covered in the review. A follow-up article (Yang et al., 2014) related to the application of bacteriocins in foods and pharmaceuticals provided some information regarding the classification, mechanism of action, and general applicability against harmful microbes, but little information was provided about its specific application in different food categories. Another related review (by Chen and Hoover, 2003) mainly discussed the classification, genetics and mode of action of bacteriocins. The main aim of the present review/paper was to bridge the gap between the food industry and bacteriocin utilization and tells about how specifically one can utilize bacteriocins to the specific food commodity.

\section{THE BACTERIOCINOGENICS}

A few bacteriocinogenics are used as cocultures that grow rapidly without interfering with the growth of the starter cultures. The bacteriocinogenics produce antimicrobials/ocins when required and are autonomous entities; therefore, their presence does not negatively affect the growth. Most or all of the probiotic microorganisms are considered bacteriocinogenic. Their presence is advantageous and useful in the production of safe foods.

\section{APPLICATIONS OF OCINS IN THE DAIRY INDUSTRY}

In 2015, the global dairy industry had an estimated milk production of 818 million tons (milk production in India during 2017 and 2018 was 176 million tons), of which 640 million tons corresponded to bovine milk. The leading producers of milk are Asia (29\%), certain European countries (79.9\%), North and Central America (18\%), South America (10\%), other European countries (9\%), Africa (5\%), and Oceania (5\%; Gilles and Nico van, 2016; Bulletin of the International Dairy Federation 485/2016 ISSN 0250-5118). A vast array of products are made from milk, including raw, pasteurized, and dried milk, cream, butter, cultured buttermilk, paneer, sour cream, cottage cheese, yogurt, yogurt-based drinks and other fermented dairy foods, cream cheese, processed cheese, fresh soft cheeses, and ripened cheeses.

In the dairy industry, the pathogenic bacteria of primary concern include those that can live and multiply quickly in milk (even at $4^{\circ} \mathrm{C}$ ) and different types of cheese, e.g., Listeria monocytogenes, Staphylococcus aureus, Escherichia coli, and Salmonella spp. (De Buyser et al., 2001). The decomposition of semi-soft and hard cheeses due to gas formation by Clostridium tyrobutericum has been responsible for substantial economic losses (Bergère and Lenoir, 2000). Nisin has been extensively tested in dairy products. For example, nisin has been used to inhibit gas production by C. tyrobutyricum in cheese (Hirsch et al., 1951; De Vuyst and Vandamme, 1994) and to inhibit Bacillus cereus growth in thermally treated cream during storage (at $5 \mathrm{IU} \mathrm{g}^{-1}$ nisin; Nissen et al., 2001). Nisin-coated polyethylene/polyamide packaging decreased the population of lactic acid bacteria (LAB), Listeria innocua, and S. aureus in packaged sliced cheese (Scannell et al., 2000). Lactococcal ocin, Lacticin 3147, was reported to have potential applications in dairy food preservation (Ross et al., 1999). Infant formulas containing lacticin 3147 suppressed the growth of $L$. monocytogenes and reduced S. aureus cell counts (Morgan et al., 1999). The viable cell counts of $L$. monocytogenes were reduced by $85 \%$ in yogurt and by $99 \%$ in cottage cheese within $2 \mathrm{~h}$ of lacticin 3147 powder addition (Morgan et al., 2001).

Parente and Hill (1992) concluced that ocin from E. faecium DPC1146 had a rapid bactericidal effect on L. monocytogenes in whole milk. Enterocin CCM 4231 reduced the active colonies of $S$. aureus SA1 in skim milk and yogurt (Lauková et al., 1999a,b). When added to goat cheese, concentrated enterocin CRL35 decreased L. monocytogenes population without affecting cheese quality (Farías et al., 1999). Similarly, pediocin PA-1/AcH decreased L. monocytogenes in several dairy products, including dressed cottage cheese, half-and-half, and cheese sauce (Pucci et al., 1988). A Propionibacterium P127 bacteriocin, propionicin PLG-1, inhibited several psychrotrophic spoilage and 
pathogenic bacteria (Listeria monocytogenes, P. fluorescens, Vibrio parahaemolyticus, Yersinia enterocolitica, and Corynebacterium sp.), suggesting a possible role as an antimicrobial food preservative (Lyon et al., 1993). Variacin, an ocin synthesized by Kocuria varians in a milk-based ingredient, hindered the growth and proliferation of $B$. cereus when added to chilled milk products, and vanilla and chocolate desserts (O’Mahony et al., 2001).

A natural variant nisin $\mathrm{Z}$ from $L$. lactis spp., lactis IPLA 729, which was identified in raw-milk cheese, reduced the growth of C. tyrobutyricum CECT 4011 (Rilla et al., 2003). Several studies (Ryan et al., 1996, 2001; Fenelon et al., 1999) have confirmed that the use of lacticin 3147-producing starters enhance cheese quality by inhibiting adventitious non-starter LAB flora during ripening. The transconjugants of lacticin 3147 effectively inhibited L. monocytogenes in cottage cheese (McAuliffe et al., 1999), mold-ripened cheese (Ross et al., 2000), and smear-ripened cheese (O'Sullivan et al., 2006). Enterocin A production resulted from a genetically modified strain of L. lactis. The starter was effectively utilized to inhibit L. monocytogenes populations in cottage cheese during the fermentation process (Liu et al., 2008). The bacteriocin of E. faecium 7C5 (Torri Tarelli et al., 1994; Folli et al., 2003) was stable for 40 days during ripening (Giraffa, 1995). The enterocin 226NWC, produced by E. faecalis 226, was active against L. monocytogenes during cocultivation in skim milk at $30^{\circ} \mathrm{C}$ (Villani et al., 1993). E. faecium CCM 4231 synthesized a bacteriocin in Saint-Paulin cheese (Lauková et al., 2001). Furthermore, E. faecium DPC 1146 produced enterocin 1146 (enterocin A), and E. faecium strain RZS C5 produced an anti-listerial bacteriocin in cheddar cheese cocultures (Foulquié Moreno et al., 2003; Leroy et al., 2003).

Thermophilin 110, produced by Streptococcus thermophilus strain ST110, is a bacteriocin that inhibits the growth of Pediococcus, a food spoilage microorganism (Gilbreth and Somkuti, 2005). The food-grade lantibiotic Macedocin synthesized by Streptococcus macedonicus ACA-DC 198 was isolated from Greek Kasseri cheese and skim milk cultures with a nitrogen supplement (Tsakalidou et al., 1998; Georgalaki et al., 2002). L. lactis CL1 and CL2 produce pediocin PA-1 and derivatives (next generation molecules) that reduce L. monocytogenes, S. aureus, and E. coli O157:H7 populations during fermentation (Rodríguez et al., 2005). The most important spoilage organisms and antagonistic bacteriocins in milk and dairy products are summarized in Table 1.

\section{APPLICATIONS OF OCINS IN MEAT AND MEAT PRODUCTS}

Meat and meat products are rich in proteins and provide a favorable environment for the proliferation of a variety of spoilage microorganisms. The availability of oxygen in meat at refrigeration temperatures allows the growth of Gram-negative aerobic bacteria, particularly Pseudomonas, and of Carnobacterium, Lactobacilli, and Leuconostoc, which predominate in anaerobic culture conditions (Borch et al., 1996; Gram and Dolgaard, 2002). Certain conditions in cooked
TABLE 1 | Bacteriocins against milk spoilage microbes and pathogens.

\begin{tabular}{lll}
\hline Products & Spoilage microbes & Bacteriocins \\
\hline Milk and milk products & Listeria monocytogenes & Nisin Z, Lacticin 3147, \\
& & Enterocin CRL35, Pediocin \\
& PA-1/AcH, propionicin \\
& PLG1 \\
& Enterocin A, Enterocin \\
& Staphylococcus aureus & 226NWC \\
& Enterocin CCM 4231, \\
& Escherichia coli & Enterocin AS-48 \\
Clostridium tyrobutyricum & Pediocin PA-1 \\
Clostridium botulinum, & Nisin Z, Thermophilin \\
Bacillus cereus & Nisin \\
& Nisin, Enterocin AS-48, \\
P. fluorescens & Variacin \\
Vibrio parahaemolyticus & Propionicin PLG-1 \\
Yersinia enterocolitica & Propionicin PLG-1 \\
Corynebacterium sp. & Propionicin PLG-1 \\
Pediococcus spp. & Propionicin PLG-1 \\
& Thermophilin 110 \\
\end{tabular}

meat products, such as low salt content $(\sim 2 \%)$, a $\mathrm{pH}$ value of approximately 6.0, a water activity value higher than 0.945 , and the absence of competing microbiota, create an ideal environment for foodborne pathogens and food spoilage microorganisms. Additionally, changes in the environmental gas composition of stored meat and meat products facilitate the growth of $\mathrm{CO}_{2}$-tolerant slow-growing bacteria, such as Lactobacilli (e.g., Lactobacillus sakei and Lactobacillus curvatus), Leuconostoc carnosum, Leuconostoc gasicomitatum, Leuconostoc mesenteroides, Weissella spp., and Carnobacterium spp. These spoilage bacteria contribute to sour taste and off-flavors, discoloration, gas, slime, and $\mathrm{pH}$ reduction (Aznar and Chenoll, 2006; Chenoll et al., 2007). Furthermore, L. monocytogenes growth and proliferation may be enhanced by meat processing conditions (Thévenot et al., 2006). Pediocin PA-1 retards the growth of Gram-positive meat spoilage microorganisms (Kalchayanand, 1990) and reduces L. monocytogenes populations (Nielsen et al., 1990) in beef. The recent studies have reported that pediocins have anti-listerial activity in meat (Motlagh et al., 1992; Taalat et al., 1993; Goff et al., 1996; Nieto-Lozano et al., 2006). The lactococcal bacteriocin lactocin 705 is useful in controlling L. monocytogenes in beef slurries (Vignolo et al., 1998) and in meat processing systems when combined with enterocin CRL35 and nisin (Vignolo et al., 2000). The addition of a freeze-dried piscicocin CS526 fermentate to ground meat reduced viable counts of $L$. monocytogenes (Azuma et al., 2007). Nisin in combination with lysozyme inhibited $B$. thermosphacta and LAB growth in vacuum-packed pork products (Nattress et al., 2001; Nattress and Baker, 2003). Various ocins, including pediocin $\mathrm{AcH}$, sakacin $\mathrm{P}$, carnobacteriocin from Carnobacterium piscicola L103, synthetic lactocin 705, and purified lactocin AL705 are effective antagonists of $B$. thermosphacta and Listeria in vacuum-packed meat products (Schlyter et al., 1993; Schöbitz et al., 1999; Katla et al., 2002; Castellano and Vignolo, 2006). Nisin was effective in preventing spoilage of bolognatype sausages by LAB (Davies and Delves-Broughton, 1999; 
TABLE 2 | Bacteriocins against meat spoilage microbes and pathogens.

\begin{tabular}{lll}
\hline Products & Spoilage microbes & Bacteriocins \\
\hline Meat and meat & Pseudomonas & - \\
products & Carnobacterium & - \\
& Lactobacillus & Nisin \\
Leuconostoc & Nisin \\
S. aureus & Enterocin AS-48, Lacticin \\
& Enterococci & 3147 \\
Brochothrix thermosphacta & Sakacin-P \\
& Nisin, Lactocin AL705 \\
& Pediocin AcH, Sakacin P, \\
& Carnobacteriocin, Lactocin \\
& Tisteria monocytogenes & Pediocin PA-1, Piscicolin \\
& CS526, Lactocin AL705 \\
& Enterocin CRL35, Nisin, \\
& Enterocin AS-48, Sakacin-P \\
& Lacticin 3147 \\
\hline
\end{tabular}

Davies et al., 1999). Nisin provided a concentration-dependent inhibition of L. monocytogenes-induced spoilage when added to sucuk, a Turkish fermented sausage (Hampikyan and Ugur, 2007). In an experimental meat sausage model, the viability of L. monocytogenes and S. aureus was inhibited with enterocin AS-48 (Ananou et al., 2005a,b). When used as a starter for sausage fermentation, a sakacin P-producing L. sakei strain reduced counts in total bacteria, fecal Enterococci, and Listeria (Urso et al., 2006). Lacticin 3147 , generated by a transconjugant of L. lactis DPC4275, significantly decreased L. innocua and S. aureus levels in beaker sausage (Scannell et al., 2001). The potential applications of bacteriocins in the meat processing industry are summarized in Table 2.

\section{APPLICATIONS OF OCINS IN THE POULTRY INDUSTRY}

The poultry industry is negatively impacted by pathogens that contribute to significant product damage and serious economic losses. The major bacterial infections in the poultry industry are caused by Vibrio cholera, Salmonella, and Clostridium. Until now, the poultry industry has relied on the exploitation of various antibiotics for the treatment of bacterial infections. However, due to the emergence of antibiotic-resistant microorganisms and the import of antibiotic-contaminated poultry products, it is important to develop suitable and efficient antibiotic alternatives. On October 25th of 2018, a legislation, which will be implemented in 2022, was approved by the European Parliament to ban the prophylactic use of antibiotics in farming. Following the ban of all animal growth-promoting antibiotics by Sweden in 1986, the European Union banned avoparcin in 1997 and bacitracin, spiramycin, tylosin, and virginiamycin in 1999. This is not only imminent to ban the prophylactic use of antibiotics, but already partially applied the prohibition in the EU for example. Protein-based antibiotic molecules, such as nisin, may be considered suitable alternatives, because they have been tested and proven effective. Nisin addition to pasteurized liquid whole eggs reduced active L. monocytogenes populations, thereby
TABLE 3 | Bacteriocins against egg spoilage microbes and pathogens.

\begin{tabular}{lll}
\hline Products & $\begin{array}{l}\text { Spoilage/Pathogenic } \\
\text { Microbes }\end{array}$ & Bacteriocins \\
\hline Egg and egg products & L. monocytogenes & Nisin, Pediocin Pa1/Ach \\
& B. cereus & Nisin \\
& Salmonella enteritidis & Nisin, Pediocin Pa1/Ach \\
& L. innocua & Nisin \\
& E. coli & Nisin \\
\hline
\end{tabular}

increasing the shelf-life of the product under refrigeration conditions and preventing the proliferation of $L$. monocytogenes and B. cereus (Delves-Broughton et al., 1992; Knight et al., 1999; Schuman and Sheldon, 2003). Pediocin Pa1/Ach and nisin are antagonistic toward L. monocytogenes and act synergistically under heat treatment (Muriana, 1996; Knight et al., 1999). Nielsen et al., 1990 increased the thermal sensitivity of Salmonella enteritidis PT4 during pasteurization of liquid whole eggs and egg whites (Boziaris et al., 1998). Nisin coupled to high-pressure treatment of liquid whole eggs significantly reduced the viable counts of E. coli and L. innocua; these microorganisms were completely denatured after a month of refrigeration (Ponce et al., 1998). Holcapkova et al. (2017) concluded that nisin loses approximately $80 \%$ of its activity between $60^{\circ} \mathrm{C}$ and $70^{\circ} \mathrm{C}$. The effects of ocins on spoilage microorganisms in the egg product industry are summarized in Table 3.

\section{APPLICATIONS OF OCINS IN THE AQUACULTURE INDUSTRY}

There are two different types of infections observed in aquaculture products, one occurs during the larval stage and the other occurs during storage. The aquaculture industry mainly cultures crabs, fish, and shrimp. Aeromonas hydrophila, Vibrio cholera, and Staphylococcus haemolyticus are the most common pathogens. A variety of microbial groups predominate during seafood storage depending on the preservation conditions and the nature of the product. In general, fish product preservation is performed with sodium chloride addition, slight acidification, and cold storage in vacuum packages. Other predominant microflora are LAB, primarily Lactobacillus, Carnobacterium, and some Gram-negative bacteria (e.g., Photobacterium phosphoreum and psychrotrophic Enterobacteriaceae). L. sakei, B. thermosphacta, Serratia liquefaciens, and P. phosphoreum were the only microorganisms that contribute to off-odors in coldsmoked salmon (CSS) samples (Stohr et al., 2001). The addition of acid or preservatives allow the growth and proliferation of lactobacilli and yeasts in some products, whereas mild heat treatment allows the propagation of surviving endospores of bacteria, such as Clostridium or Bacillus (Lindström et al., 2006).

Early studies have shown that nisin was not a suitable antagonist of L. monocytogenes in CSS because it only inhibited (i.e., was bacteriostatic, but not bactericidal) the growth in vacuum-packed fish products (Nilsson et al., 1997). However, nisin coupled with radio-frequency (RF) heating synergistically destroyed L. innocua and all mesophilic microorganisms. 
TABLE 4 | Bacteriocins against sea food spoilage microbes and pathogens.

\begin{tabular}{lll}
\hline Products & $\begin{array}{l}\text { Spoilage/Pathogenic } \\
\text { Microbes }\end{array}$ & Bacteriocins \\
\hline Fish and other sea foods & $\begin{array}{l}\text { Lactobacillus } \\
\text { Carnobacterium } \\
\text { Photobacterium phosphoreum }\end{array}$ & Nisin \\
& Psychrotrophic & - \\
& Enterobacteriaceae & \\
& Clostridium & Nisin \\
& L. monocytogenes & Nisin, Sakacin P \\
& L. innocua & Nisin \\
\hline
\end{tabular}

Populations of L. innocua in sturgeon caviar or ikura were killed at $65^{\circ} \mathrm{C}$ with RF-nisin treatment (Al-Holy et al., 2004). Nisin combined with heat or antimicrobial compounds inhibited L. monocytogenes and total mesophiles in sturgeon caviar (AlHoly et al., 2005). Nisin Z, carnocin UI49, and bavaricin A, either in purified or crude form, have been evaluated for their ability to enhance the shelf-life of brined shrimp (Einarsson and Lauzon, 1995). The inoculation of CSS with cultures of L. sakei L6790, a sakacin P-producing strain, had a bacteriostatic effect on L. monocytogenes, similar to the effects of an isogenic L. sakei strain. Incomplete inactivation of L. monocytogenes was achieved when a sub-lethal concentration of purified sakacin $\mathrm{P}$ was combined with a bacteriocinogenic culture (Katla et al., 2001). The bacteriocins antagonistic to spoilage microorganisms present in seafood are summarized in Table 4.

\section{APPLICATIONS OF OCINS IN FRUITS, SPROUTS, AND VEGETABLE INDUSTRY}

This category of food includes unprocessed fruits and vegetables, processed ready-to-eat vegetables, canned products, fermented vegetables, fruit juices, drinks, and beverages. Sprouts have been consumed for many centuries in Asia and for 30 years in other parts of the world (Rosas and Escartin, 2000). Sprouts, which are considered to be a health food, are sources of foodborne illnesses caused by Salmonella, E. coli O157, and B. cereus (Beuchat, 1996, 2002; Taormina et al., 1999). Fresh produce, including raw celery, tomatoes, and lettuce, has been implicated in several listeriosis outbreaks (Beuchat, 1996). One of the most significant applications of bacteriocins is via competitive exclusion, in which nonpathogenic microorganisms inhibit the growth and proliferation of pathogens during sprouting. There are several reports on the isolation and identification of natural microorganisms from fresh produce that secrete antimicrobial substances (Carlin et al., 1996; Buchanan and Bagi, 1999; Liao and Fett, 2001; Wilderdyke et al., 2004). Among these microorganisms, the most effective are LAB strains that inhibit the growth of pathogenic microorganisms in ready-to-eat vegetables (Vescovo et al., 1996). Lactococci, which produce nisin, reduced L. monocytogenes populations in bean sprouts during refrigeration (Cai et al., 1997). Mundticin-producing strains of Enterococcus mundtii isolated from minimally processed vegetables prevented the growth of L. monocytogenes in a sterile vegetable medium (Bennik et al., 1999). Mundticin was an effective preservative for mung bean sprouts stored in a modified atmosphere (Bennik et al., 1999). Erwinia carotovora subsp. carotovora is a highly effective spoilage microorganism that causes soft rot in vegetables and fruits. The use of bacteriocins produced ex situ may avoid problems associated with in situ ocin secretion in vegetable foods.

There are no reports on any harmful effects of ocins on vegetable cells or tissues. Consequently, ocins might be suitable for the prevention of spoilage in fruits and vegetables, when either used alone or in combination with sanitizers. González-Pérez et al. (2018) induced bacteriocins in LAB to prevent spoilage in fruits and vegetables. However, the regrowth of surviving spoilage organisms of treated foods during storage needs to be taken into account. Pediocin, when used alone or with organic acid, was more effective than nisin alone in reducing L. monocytogenes populations (Bari et al., 2005).

Enterocin AS-48 was highly antagonistic toward S. aureus and completely inactivated L. monocytogenes and B. cereus in lettuce juice (Grande et al., 2005b). Nisin inhibited the growth of L. monocytogenes in honeydew melon slices, and its activity was increased when combined with a phage (Leverentz et al., 2003). Nisin was not effective in controlling spoilage of fruit in yogurt (Penney et al., 2004). In canned mango pulp, both nisin and bovicin HC5 inhibited C. tyrobutyricum growth and subsequent gas production (de Carvalho et al., 2007). In canned and cooked vegetables, endospore-forming bacteria are the main source of contamination. Several studies have confirmed that bacteriocins may eliminate endospore growth and proliferation and enhance the efficacy of thermal treatments to eradicate endospores in canned and cooked vegetables. In canned vegetables, nisin inhibited spoilage by non-aciduric (Bacillus stearothermophilus and Clostridium thermosaccharolyticum) and aciduric (Clostridium pasteurianum, Bacillus macerans, Bacillus coagulans) endospore-forming microorganisms (Thomas et al., 2000).

Nisin addition during processing resulted in a complete inhibition of bacterial growth and a 30-day extension in the shelf-life of pasteurized and vacuum-packed mashed potatoes when incubated in the presence of Clostridium sporogenes and C. tyrobutyricum spores (Thomas et al., 2002). The spoilage of fruit juices and beverages by Alicyclobacillus has been prevented with nisin addition (Komitopoulou et al., 1999; Yamazaki et al., 2000). Enterocin AS-48 completely inactivated Alicyclobacillus acidoterrestris for 3 months after inoculation of several fruit juice samples (Grande et al., 2005a). Nisin and enterocin AS-48 inactivated A. acidoterrestris endospores (Komitopoulou et al., 1999; Yamazaki et al., 2000; Grande et al., 2005a). In addition, enterocin CCM4231 produced by the enterococcal strain CCM4231 completely inhibited the growth of L. monocytogenes in soy milk and significantly decreased the viable counts of S. aureus (Lauková and Czikková, 1999). Nisin restricted the proliferation of $B$. stearothermophilus in soy milk and of thermophilic Clostridia in coconut milk/water (Thomas et al., 2000).

Potential biological control agents in the brewing industry include novel ocins produced by bacteriocinogenic strains of L. sakei and L. mesenteroides isolated from malted barley (Vaughan et al., 2001). Thermophilin 110 is antagonistic toward 
TABLE 5 | Bacteriocins against fruit and vegetable spoilage microbes and pathogens.

\begin{tabular}{lll}
\hline Products & Spoilage/Pathogenic Microbes & \multicolumn{1}{c}{ Bacteriocins } \\
\hline Fruits and & Salmonella & Nisin \\
vegetable & E. coli O157 & - \\
& B. cereus & Enterocin AS-48 \\
L. monocytogenes & Mundticin, Pediocin, \\
& & Enterocin AS-48, Nisin, \\
& Clostridium sporogenes & Enterocin CCM4231 \\
& Alicyclobacillus acidoterrestris & Nisin \\
& Staphylococcus aureus & Nisin, Enterocin AS-48 \\
& Enterocin AS-48, \\
& C. tyrobutyricum & Enterocin CCM4231 \\
Bacillus stearothermophilus & Bovicin HC5, Nisin \\
Clostridium thermosaccharolyticum & Nisin \\
Clostridium pasteurianum & Nisin \\
Bacillus macerans & Nisin \\
Bacillus coagulans & Nisin \\
B. stearothermophilus & Nisin \\
Pediococci & Nisin \\
O. oeni & Thermophilin 110 & Pediocin PD-1 \\
& &
\end{tabular}

pediococcal strains (Gilbreth and Somkuti, 2005). Pediocin N5p from $P$. pentosaceus is resistant to physicochemical conditions of vinification including $\mathrm{pH}$, temperature, ethanol, and $\mathrm{SO}_{2}$ (Strasser de Saad et al., 1995). Pediocin PD-1 synthesized by $P$. pentosaceus in beer was more effective than nisin and plantaricin 423 in the removal of mature O. oeni biofilms from stainless steel surfaces of tanks containing Chardonnay must (Nel et al., 2002). O. oeni can be effectively controlled in wine with the addition of pediocin PD-1 (Bauer et al., 2003). The main bacteriocins against fruit and vegetable spoilage microorganisms are summarized in Table 5.

\section{APPLICATIONS OF OCINS IN CEREALS, PULSES, AND LEGUMES}

LAB bacteriocins ensure the safety and quality of cereal- and legume-based fermented foods. L. lactis subsp. lactis IFO12007, which produces nisin, was isolated from miso and used as a starter culture in the fermentation of cooked rice and soybean extract-supplemented rice koji. The bacteriocin-producing strain was grown in cooked rice and synthesized sufficient nisin to hinder the growth of $B$. subtilis without negatively affecting the growth of Aspergillus oryzae, which is needed in koji fermentation (Kato et al., 2001). Bacterial strains that negatively affect the long-term storage of cereals and pulses are presented in Table 6.

\section{APPLICATIONS OF OCINS IN THE BAKING INDUSTRY}

Rope spoilage is due to less acidification, and also the presence of large amounts of sugar, fat or fruit (Beuchat, 1997). Therefore, the rope spoilage of wheat bread is a major concern in the baking industry. The main microorganism responsible for rope spoilage is B. subtilis; however, B. licheniformis, B. megaterium,
TABLE 6 | Bacteriocins against cereals and pulses spoilage microbes and pathogens.

\begin{tabular}{lcc}
\hline Products & Spoilage microbe & Bacteriocins \\
\hline Cereals and pulses & B. subtilis & Nisin \\
\hline
\end{tabular}

TABLE 7 | Most common food preservatives, food additives and conventional ingredients and their percentage used in food.

\begin{tabular}{lc}
\hline Preservatives & Percentage used \\
\hline Sodium chloride & 2 and $4 \%$ \\
Sucrose & $1 \%$ \\
Acetic acid & 0.1 and $0.3 \%$ \\
Ascorbic acid & 0.015 and $0.055 \%$ \\
Benzoic acid & 0.05 and $0.1 \%$ \\
Sodium benzoate & 0.05 and $0.1 \%$ \\
Sodium sulfite & 0.05 and $0.25 \%$ \\
Sodium metabisulfite & 0.05 and $0.25 \%$ \\
Potassium metabisulfite & 0.05 and $0.25 \%$ \\
Sodium nitrate & 0.02 and $0.05 \%$ \\
Sorbic acid & 0.025 and $0.1 \%$ \\
Tartaric acid & $1 \%$ \\
Citric acid & 0.02 and $0.035 \%$ \\
Calcium propionate & 0.1 and $0.4 \%$ \\
\hline
\end{tabular}

and $B$. cereus may also be involved. B. subtilis and B. licheniformis have been inhibited in bread by nisaplin nisaplin ${ }^{\mathrm{R}}$ and nisinproducing LAB (Rosenquist and Hansen, 1998). The addition of nisin as a powder prevents food spoilage caused by Grampositive bacteria. However, as nisin is thermolabile, it needs to be incorporated following exposure to high temperatures.

\section{ACTION OF OCINS IN THE PRESENCE OF FOOD PRESERVATIVES, ANTIOXIDANTS, AND INGREDIENTS}

Food processing is both a technique and an art. Food processing techniques adopted by most modern industries help retain food flavors for long periods of time or until the product reaches the consumer. Therefore, food processing not only ensures that the product is free of harmful pathogens and contaminants, but assists in retaining flavors and colors. The most commonly used food additives and antioxidant additives include sodium chloride, sucrose, acetic acid, ascorbic acid, benzoic acid, sodium benzoate, and sodium sulfite. The food preservatives and additives and their percentage used in food products are summarized in Table 7. Future studies should investigate the stability and functionality of ocins in the presence and absence of these additives.

\section{THE NEED FOR HETEROLOGOUS EXPRESSION AND PRODUCTION OF RECOMBINANT OCINS}

Currently, ocin production is achieved by isolating the compound from cultured ocin-producing bacterial strains. 
This approach relies on the microorganisms and specific conditions under which high ocin expression may be feasible. The current demand for ocins is very high. Therefore, it is important to explore innovative ways of ocin production, e.g., via genetically engineered microorganisms such as E. coli and Lactococcus lactis. Between these microorganisms, E. coli is preferred because its genetic system is understood and can be exploited for the expression of any gene of interest (Beatriz et al., 2018). Even though several different expression hosts have been identified, BL21 DE3 and the plasmid pET are optimum (Studier and Moffatt, 1986; Rosenberg et al., 1987; Studier et al., 1990).

Most ocins are ribosomally derived; therefore, they cannot be cloned and expressed with a specific promoter. To express a specific ocin, a basic machinery for its synthesis and secretion is required. It is crucial to develop plasmids that contain the secretory signal, permease, the immunity gene, and the structural gene as a cluster. The construct needs to be made so that any open reading frame (ORF) coding for ocin may be easily introduced into the cassette for expression. Ultimately, the whole cassette should be inserted and directed under different promoters according to the demand. The promoter may be selected based on the characteristics of the ocins. A few ocins are toxic in nature; however, as soon as expression begins, they might have toxic effects on the host, leading to death. Therefore, it is important to exercise caution when selecting the promoter. Mesa-Pereira et al. (2018) discussed the production of ocins in heterologous hosts.

\section{LIMITATIONS OF OCINS}

Even though bacteriocins may be used in the food industry to eradicate disease-causing agents, they have some limitations. Considering that only hyperactive antimicrobial-producing strains may be considered for academic and commercialization purposes, there is no focus toward probiotic microorganisms that synthesize and secrete minimal quantities of ocins. Bacillus licheniformis, a GRAS microorganism, causes rope spoilage in apple cider (Grande et al., 2006).

The efficacy of bacteriocins might be product-dependent, e.g., the effectiveness of enterocin AS-48 against $S$. aureus is reduced in carbonara sauce (Grande et al., 2007). Chen and Hoover (2003) reported that moderate antimicrobial effects and limited specificity (narrow spectra) are major limitations in the application of bacteriocins in the food industry. Additionally, some bacteria are resistant to bacteriocins, e.g., Listeria is resistant to nisin, piscicosin, and pediocin (Gravesen et al., 2002; Martinez et al., 2005; Hayashi, 2007). Certain ocins may be inactivated by food components, and ocins may adsorb to the surface of the food, leading to proteolytic degradation. Information on the inactivation of bacteriocins in foods has been reported by Jung et al. (1992) and Ghalfi et al. (2007). The practical and daily problems faced by using ocins in food industry (for food preservation) are inactivated by food components a major problem. It is almost impossible to find the exact cause of inhibition.

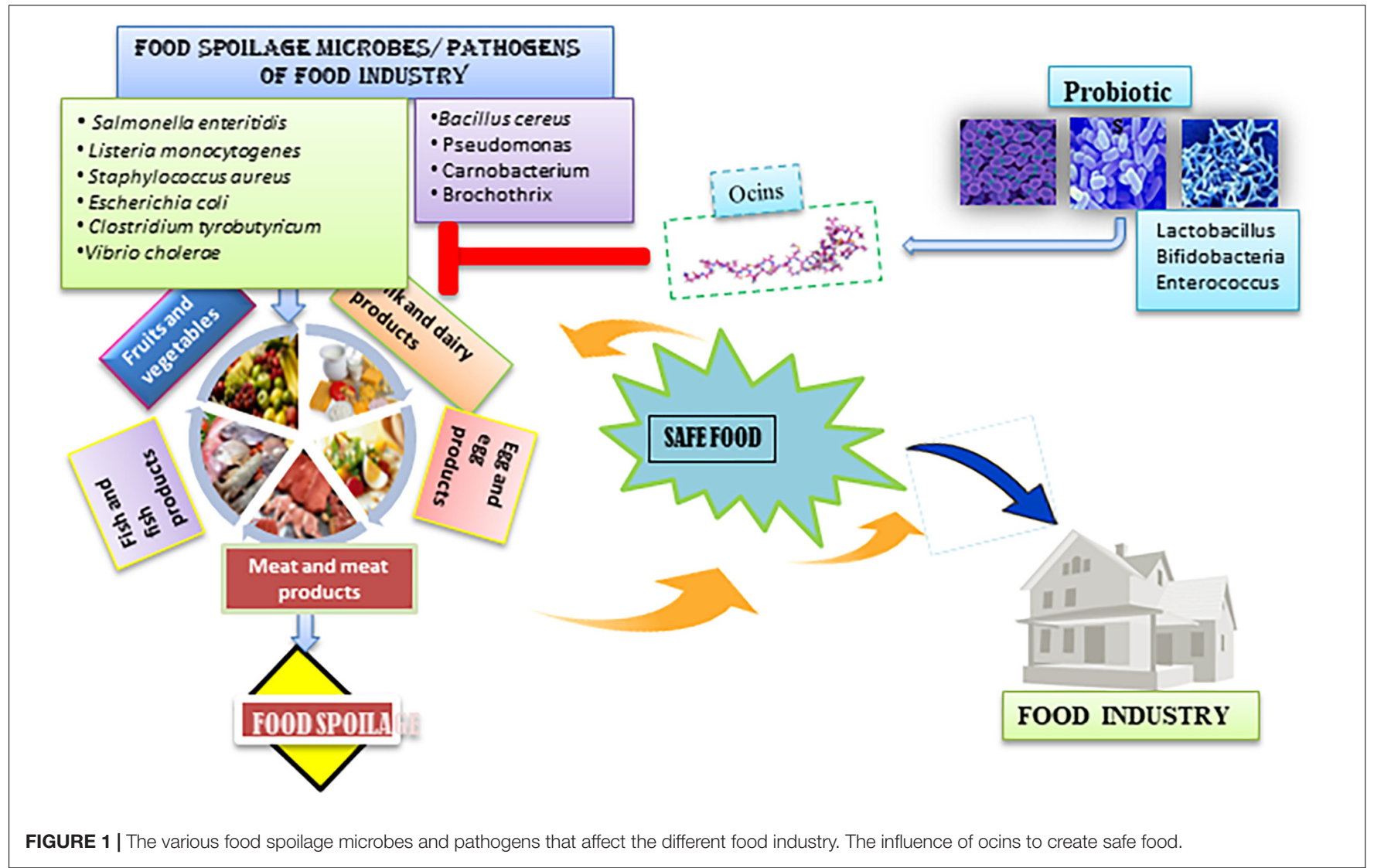


Collagen-like substances in food products or in supernatants of Pichia pastoris inhibited pediocin-PA1 bacteriocin activity (Beaulieu et al., 2005). Even though bacteriocins are not chemical-based compounds, they may alter food flavors and taste. It has been reported that the introduction of a few bacteriocins to foods results in loss of taste and in changes in odor (Drider et al., 2006). Regulatory concerns in developed countries hinder the applications of bacteriocins in the food industry. The various food spoilage microbes and pathogens that affect the different food industry and influence of ocins to create safe food has been depicted in the Figure 1.

\section{CONCLUSION AND FUTURE PERSPECTIVES}

The applications of bacteriocins in food processing have been researched, with significant efforts devoted toward the preservation of meat and dairy products. Ocins may be highly effective in the preservation of fish, fruit, and vegetable products. Ocins, whether produced ex situ and added during processing or produced in situ by bacteriocinogenic strains, provide a natural antimicrobial barrier against pathogenic and spoilage bacteria. Several studies have focused on the introduction of bacteriocinogenic strains in foods. Compared with ex situ preparations, in situ ocin production offers several advantages. The scientific community is concerned about the use of chemicals and other food preservatives that might adversely affect human health. Ocins are natural compounds isolated from probiotic GRAS bacteria that are suitable preservatives in food and food products. Further studies are required to understand the mechanism of action of ocins. Modern biological

\section{REFERENCES}

Algburi, A., Comito, N., Kashtanov, D., Dicks, L. M., and Chikindas, M. L. (2017). Control of biofilm formation: antibiotics and beyond. Appl. Environ. Microbiol. 83:e2508-16. doi: 10.1128/AEM.02508-16

Al-Holy, M., Lin, M., and Rasco, B. (2005). Destruction of Listeria monocytogenes in sturgeon (Acipenser transmontanus) caviar by a combination of nisin with chemical antimicrobials or moderate heat. J. Food Prot. 68, 512-520. doi: 10.4315/0362-028x-68.3.512

Al-Holy, M., Ruiter, J., Lin, M., Kang, D. H., and Rasco, B. (2004). Inactivation of Listeria innocua in nisin-treated salmon (Oncorhynchus keta) and sturgeon (Acipenser transmontanus) caviar heated by radio frequency. J. Food Prot. 67, 1848-1854. doi: 10.4315/0362-028x-67.9.1848

Ananou, S., Garriga, M., Hugas, M., Maqueda, M., Martínez-Bueno, M., Gálvez, A., et al. (2005a). Control of Listeria monocytogenes in model sausages by enterocin AS-48. Int. J. Food Microbiol. 103, 179-190. doi: 10.1016/j.ijfoodmicro.2004. 12.024

Ananou, S., Maqueda, M., Martínez-Bueno, M., Gálvez, A., and Valdivia, E. (2005b). Control of Staphylococcus aureus in sausages by enterocin AS-48. Meat Sci. 71, 549-576. doi: 10.1016/j.meatsci.2005.04.039

Aznar, R., and Chenoll, E. (2006). Intraspecific diversity of Lactobacillus curvatus, L. plantarum, L. sakei, and Leuconostoc mesenteroides associated with vacuumpacked meat product spoilage analyzed by randomly amplified polymorphic DNA PCR. J. Food Prot. 69, 2403-2410. doi: 10.4315/0362-028x-69. 10.2403

Azuma, T., Bagenda, D. K., Yamamoto, T., Hawai, Y., and Yamazaki, K. (2007). Inhibition of Listeria monocytogenes by freeze-dried piscicocin CS526 techniques should be exploited to increase ocin production in heterologous hosts that will subsequently increase applications in the food industry. The ocin database developed by the Kammara group and available at ocins.cftri.com/ocins/ is the first database detailing food products, spoilage microorganisms, and corresponding bacteriocins. The information presented in the database might assist in the development of safe foods for the food industry (Choyam et al., 2019).

\section{AUTHOR CONTRIBUTIONS}

SC executed the idea. RK conceived, planned, designed the study, analyzed the data, interpreted the results, and wrote the manuscript. AS reviewed and prepared the final manuscript. J-HS involved in modifying the manuscript during the revision and contributed by introduction of data such as limitations, Bacteriocinogenics etc.

\section{FUNDING}

We appreciate and acknowledge the funding received from the Life Science Research Board-DRDO, Ministry of Food Processing Industries (MoFPI), New Delhi.

\section{ACKNOWLEDGMENTS}

RK acknowledges the contributions of J-HS, his collaborator and the chair Department of Applied Biosciences, Kyungpook National University, South Korea. Brain Pool by NRF is highly appreciated.

fermentate in food. Lett. Appl. Microbiol. 44, 138-144. doi: 10.1111/j.1472765x.2006.02054.x

Bari, M. L., Ukuku, D. O., Kawasaki, T., Inatsu, Y., Isshiki, K., and Kawamoto, S. (2005). Combined efficacy of nisin and pediocin with sodium lactate, citric acid, phytic acid, and potassium sorbate and EDTA in reducing the Listeria monocytogenes population of inoculated fresh-cut produce. J. Food Prot. 68, 1381-1387. doi: 10.4315/0362-028x-68.7.1381

Bauer, R., Nel, H. A., and Dicks, L. M. T. (2003). Pediocin PD-1 as a method to control growth of Oenococcus oeni in wine. Am. J. Enol. Vitic. 54, 86-91.

Beatriz, P., Mary, C. R., Paul, D. C., Colin, H., and Ross, R. P. (2018). Heterologous expression of biopreservative bacteriocins with a view to low cost production. Front. Microbiol. 9:1654. doi: 10.3389/fmicb.2018.01654

Beaulieu, L., Groleu, D., Miguez, C. B., Jette, J. F., Aomari, H., and Subirade, M. (2005). Production of pediocin PA-1 in methylotrophic yeast Pichia pastoris reveals unexpected inhibition of its biological activity due to the presence of collagen -like material. Protein Expr. Purif. 43, 111-125. doi: 10.1016/j.pep. 2005.05.012

Bennik, M. H. J., van Overbeek, W., Smid, E. J., and Gorris, L. G. M. (1999). Biopreservation in modified atmosphere stored mungbean sprouts: the use of vegetable-associated bacteriocinogenic lactic acid bacteria to control the growth of Listeria monocytogenes. Lett. Appl. Microbiol. 28, 226-232. doi: 10.1046/j. 1365-2672.1999.00497.x

Bergère, J. L., and Lenoir, J. (2000). "Cheese manufacturing accidents and cheese defects," in Cheesemaking: From Science to Quality Assurance, 2nd Edn, eds A. Eck and J. C. Gillis (London: Intercept Ltd.), 477-518.

Beuchat, L. R. (1996). Pathogenic microorganisms associated with fresh produce. J. Food Prot. 59, 204-216. doi: 10.4315/0362-028X-59.2.204 
Beuchat, L. R. (2002). Ecological factors influencing survival and growth of human pathogens on raw fruits and vegetables. Microb. Infect. 4, 413-423. doi: 10.1016/ s1286-4579(02)01555-1

Beuchat, L. R. (ed.). (1997). "Traditional fermented foods," in Food MicrobiolFundamentals and Front (Washington, DC: ASM Press), 629-648.

Borch, E., and Agerhem, H. (1992). Chemical, microbial and sensory changes during the anaerobic cold storage of beef inoculated with a homofermentative Lactobacillus sp. or a Leuconostoc sp. Int. J. Food Microbiol. 15, 99-108. doi: 10.1016/0168-1605(92)90139-t

Borch, E., Kant-Muermans, M. L., and Blixt, Y. (1996). Bacterial spoilage of meat and cured meat products. Int. J. Food Microbiol. 33, 103-120. doi: 10.1016/ 0168-1605(96)01135-X

Boziaris, I. S., Humpheson, L., and Adams, M. R. (1998). Effect of nisin on heat injury and inactivation of Salmonella enteritidis PT4. Int. J. Food Microbiol. 43, 7-13. doi: 10.1016/s0168-1605(98)00083-x

Breukink, E., Wiedemann, I., van Kraaij, C., Kuipers, O. P., Sahl, H. G., de Kruijff, B., et al. (1999). Use of the cell wall precursor lipid II by a pore-forming peptide antibiotic. Science 286, 2361-2364. doi: 10.1126/science.286.5448.2361

Buchanan, R. L., and Bagi, L. K. (1999). Microbial competition: effect of Pseudomonas fluorescens on the growth of Listeria monocytogenes. Food Microbiol. 16, 523-529. doi: 10.1006/fmic.1998.0264

Cai, Y., Ng, L. K., and Farber, J. M. (1997). Isolation and characterization of nisinproducing Lactococcus lactis subsp. lactis from bean sprouts. J. Appl. Microbiol. 83, 499-507. doi: 10.1046/j.1365-2672.1997.00262.x

Carlin, F., Nguyen-The, C., and Morris, C. E. (1996). Influence of background microflora on Listeria monocytogenes on minimally processed fresh broadleaved endive (Cichorium endivia var. latifolia). J. Food Prot. 59, 698-703. doi: 10.4315/0362-028X-59.7.698

Castellano, P., and Vignolo, G. (2006). Inhibition of Listeria innocua and Brochothrix thermosphacta in vacuum-packaged meat by addition of bacteriocinogenic Lactobacillus curvatus CRL705 and its bacteriocins. Lett. Appl. Microbiol. 43, 194-199. doi: 10.1111/j.1472-765x.2006.01933.x

Chen, H., and Hoover, D. G. (2003). Bacteriocins and their food applications. Compr. Rev. Food Sci. Food Saf. 2, 81-100.

Chenoll, E., Macian, M. C., Elizaquivel, P., and Aznar, R. (2007). Lactic acid bacteria associated with vacuum-packaged cooked-meat product spoilage: population analysis by rDNA-based methods. J. Appl. Microbiol. 102, 498-508.

Chikindas, M. L., Venema, k., Ledeboer, A. M., Venema, G., and Kok, J. (1995). Expression of lactococcin A and pediocin PA-I in heterologous hosts. Lett. Appl. Microbiol. 21, 183-189. doi: 10.1111/j.1472-765X.1995.tb01037.x

Chopra, L., Singh, G., Kumar Jena, K., and Sahoo, D. K. (2015). Sonorensin: a new bacteriocin with potential of an anti-biofilm agent and a food biopreservative. Sci. Rep. 5:13412. doi: 10.1038/srep13412

Choyam, S., Suresh, P. S. N., Rahul, P., and Rajagopal, K. (2019). Ocins database: a database of bug-busters from Bifidobacterium, Lactobacillus, and Enterococcus. Access Microbiol. 6:1034. doi: 10.1099/acmi.0.000034

Davies, E. A., Catherine, F. M., Helen, E. B., Richard, W. P., Jo, M. H., Graham, C. W., et al. (1999). Effective use of Nisin to control Lactic acid bacterial spoilage in vacuum packed Bologna type sausage. J. Food Prot. 62, 1004-1010. doi: $10.4315 / 0362-028 \mathrm{x}-62.9 .1004$

Davies, E. A., and Delves-Broughton, J. (1999). "Nisin," in Encyclopedia of Food Microbiology, eds R. Robinson, C. Batt, and P. Patel (London: Academic Press), 191-198.

Davison, W. M., Pitts, B., and Stewart, P. S. (2010). Spatial and temporal patterns of biocide action against Staphylococcus epidermidis biofilms. Antimicrob. Agents Chemother. 54, 2920-2927. doi: 10.1128/AAC.01734-09

De Buyser, M. L., Dufour, B., Maire, M., and Lafarge, V. (2001). Implication of milk and milk products in food-borne diseases in France and in different industrialised countries. Int. J. Food Microbiol. 67, 1-17. doi: 10.1016/s01681605(01)00443-3

de Carvalho, A. A., Mantovani, H. C., and Vanetti, M. C. (2007). Bactericidal effect of bovicin HC5 and nisin against Clostridium tyrobutyricum isolated from spoiled mango pulp. Lett. Appl. Microbiol. 45, 68-74. doi: 10.1111/j.1472-765x. 2007.02150.x

De Vuyst, L., and Vandamme, E. J. (1994). "Nisin, a lantibiotic produced by Lactococcus lactis subsp. lactis: properties, biosynthesis, fermentation and applications," in Bacteriocins of Lactic Acid Bacteria, eds L. De Vuyst and E. J. Vandamme (Boston, MA: Springer), 151-222.
Delves-Broughton, J., Williams, G. C., and Wilkinson, S. (1992). The use of bacteriocin, nisin, as a preservative in pasteurized liquid whole egg. Lett. Appl. Microbiol. 15, 133-136. doi: 10.1111/j.1472-765X.1992.tb00746.x

Dosler, S., and Karaaslan, E. (2014). Inhibition and destruction of Pseudomonas aeruginosa biofilms by antibiotics and antimicrobial peptides. Peptides 62, 32-37. doi: 10.1016/j.peptides.2014.09.021

Drider, D., Fimland, G., Hechard, Y., McMullen, L. M., and Prevost, H. (2006). The continuing story of Class IIA bacteriocin. Microbiol. Mol. Biol. Rev. 70, 564-582. doi: 10.1128/mmbr.00016-05

Drosinos, E. H., and Board, R. G. (1995). Attributes of microbial associations of meat growing as xenic batch cultures in a meat juice at $4{ }^{\circ} \mathrm{C}$. Int. J. Food Microbiol. 26, 279-293. doi: 10.1016/0168-1605(94)00131-o

Duarte, A. F. S., Duarte, A. F. S., Ceotto-Vigoder, H., Barrias, E. S., SoutoPadrón, T. C. B. S., Nes, I. F., et al. (2017). Hyicin 4244, the first sactibiotic described in staphylococci, exhibits an anti-staphylococcal biofilm activity. Int. J. Antimicrob. Agents 51, 349-356. doi: 10.1016/j.ijantimicag.2017.06.025

Einarsson, H., and Lauzon, H. L. (1995). Biopreservation of brined shrimp (Pandalus borealis) by bacteriocins from lactic acid bacteria. Appl. Environ. Microbiol. 61, 669-676.

Farías, M. E., Nuñez de Kairuz, M., Sesma, F., Palacios, J., de Ruiz Holgado, A. P., and Oliver, G. (1999). Inhibition of Listeria monocytogenes by the bacteriocin enterocin CRL35 during goat cheese making. Milchwissenschaft 54, 30-32.

Fenelon, M. A., Ryan, M. P., Rea, M. C., Guinee, T. P., Ross, R. P., Hill, C., et al. (1999). Elevated temperature ripening of reduced fat cheddar made with or without lacticin 3147 producing starter culture. J. Dairy Sci. 82, 10-22. doi: 10.3168/jds.s0022-0302(99)75203-3

Field, D., Cotter, P. D., Hill, C., and Ross, R. P. (2015a). Bioengineering lantibiotics for therapeutic success. Front. Microbiol. 6:1363. doi: 10.3389/fmicb.2015.01363

Field, D., Cotter, P. D., Ross, R. P., and Hill, C. (2015b). A bioengineered nisin derivative to control biofilms of Staphylococcus pseudintermedius. PLoS One 10:e119684. doi: 10.1371/journal.pone.0119684

Field, D., Cotter, P. D., Ross, R. P., and Hill, C. (2015c). Bioengineering of the model lantibiotic nisin. Bioengineered 6, 187-192. doi: 10.1080/21655979.2015. 1049781

Flemming, H. C., and Wingender, J. (2010). The biofilm matrix. Nat. Rev. Microbiol. 8, 623-633. doi: $10.1038 /$ nrmicro2415

Folli, C., Ramazzina, I., Arcidiaco, P., Stoppini, M., and Berni, R. (2003). Purification of bacteriocin AS-48 from an Enterococcus faecium strain and analysis of the gene cluster involved in its production. FEMS Microbiol. Lett. 221, 143-149. doi: 10.1016/s0378-1097(03)00176-9

Foulquié Moreno, M. R., Rea, M. C., Cogan, T. M., and De Vuyst, L. (2003). Applicability of a bacteriocin-producing Enterococcus faecium as a co-culture in cheddar cheese manufacture. Int. J. Food Microbiol. 81, 73-84. doi: 10.1016/ s0168-1605(02)00167-8

Garrett, T. G., Bhakoo, M., and Zhang, Z. (2008). Bacterial adhesion and biofilms on surfaces. Prog. Nat. Sci. 18, 1049-1056. doi: 10.1016/j.pnsc.2008. 04.001

Georgalaki, M. D., Van den Berghe, E., Kritikos, D., Devreese, B., Van Beeumen, J., Kalantzopoulos, G., et al. (2002). Macedocin, a food-grade lantibiotic produced by Streptococcus macedonicus ACA-DC 198. Appl. Environ. Microbiol. 68, 5891-5903. doi: 10.1128/aem.68.12.5891-5903.2002

Ghalfi, H., Benkerroum, N., Doguiet, D. D. K., Bensaid, M., and Thonart, P. (2007). Effectiveness of cell -adsorbed bacteriocin produced by Lactobacillus curvatus CWB1-B28 and selected essential oils to control Listeria monocytogenes in pork meat during cold storage. Lett. Appl. Microbiol. 44, 268-273. doi: 10.1111/j. 1472-765x.2006.02077.x

Gilbreth, S. E., and Somkuti, G. A. (2005). Thermophilin 110: a bacteriocin of Streptococcus thermophilus ST110. Curr. Microbiol. 51, 175-182. doi: 10.1007/ s00284-005-4540-7

Gilles, F., and Nico van, B. (2016). The World Dairy Situation 2016. Bulletin of the International Dairy Federation No. 485/2016.

Giraffa, G. (1995). Enterococcal bacteriocins: their potential as anti-Listeria factors in dairy technology. Food Microbiol. 12, 291-299. doi: 10.1016/s0740-0020(95) 80109-x

Goff, J. H., Bhunia, A. K., and Johnson, M. G. (1996). Complete inhibition of low levels of Listeria monocytogenes on refrigerated chicken meat with pediocin AcH bound to heat-killed Pediococcus acidilactici cells. J. Food Prot. 59, 11871192. doi: 10.4315/0362-028X-59.11.1187 
González-Pérez, C. J., Aispuro-Hernández, E., Vargas-Arispuro, I., and MartínezTéllez, M. A. (2018). Induction of bacteriocins from lactic acid bacteria; a strategy to improve the safety of fresh fruits and vegetables. Agric. Res. Technol. Open Access J. 14:4.

Gram, L. (1989). Identification, Characterization and Inhibition of Bacteria Isolated from Tropical Fish. Ph.D. thesis, Danish Institute for Fisheries Research, Copenhagen.

Gram, L., and Dolgaard, P. (2002). Fish spoilage bacteria-problems and solutions. Curr. Opin. Biotechnol. 13, 262-266. doi: 10.1016/s0958-1669(02)00309-9

Grande, M. J., Lopez, R. L., Abriouel, H., Valdivia, E., Omar, N. B., Maqueda, M., et al. (2007). Treatment of vegetable sauces with enterocin AS-48 alone or in combination with phenolic compounds to inhibit proliferation of Staphylococcus aureus. J. Food Prot. 70, 405-411. doi: 10.4315/0362-028x-70. 2.405

Grande, M. J., Lucas, R., Abriouel, H., Ben Omar, N., Maqueda, M., MartínezBueno, M., et al. (2005a). Control of Alicyclobacillus acidoterrestris in fruit juices by enterocin AS-48. Int. J. Food Microbiol. 104, 289-297. doi: 10.1016/ j.ijfoodmicro.2005.03.010

Grande, M. J., Lucas, R., Valdivia, E., Abriouel, H., Maqueda, M., MartínezCañamero, M., et al. (2005b). Stability of enterocin AS-48 in fruit and vegetable juices. J. Food Prot. 68, 2085-2094. doi: 10.4315/0362-028x-68.10.2085

Grande, M. J., Lucas, R., Abriouel, H., Valdivia, E., Omar, N. B., Maqueda, M., et al. (2006). Inhibition of Bacillus licheniformis LMG 19409 from ropy cider by enterocin As-48. J. Appl. Microbiol. 101, 422-428. doi: 10.1111/j.1365-2672. 2006.02942.x

Gravesen, A., Jydegaard Axelsen, A. M., Mendes da Silva, J., Hansen, T. B., and Knechel, S. (2002). Frequency of Bacteriocin resistance development and associated fitness costs in Listeria monocytogenes. Appl. Environ. Microbiol. 68, 756-764. doi: 10.1128/aem.68.2.756-764.2002

Hampikyan, H., and Ugur, M. (2007). The effect of nisin on L. monocytogenes in Turkish fermented sausages (sucuks). Meat Sci. 76, 327-332. doi: 10.1016/j. meatsci.2006.11.014

Hatziioanou, D., Gherghisan-Filip, C., Saalbach, G., Horn, N., Wegmann, U., Duncan, S. H., et al. (2017). Discovery of a novel lantibiotic nisin O from Blautia obeum A2-162, isolated from the human gastrointestinal tract. Microbiology 163, 1292-1305. doi: 10.1099/mic. 0.000515

Hayashi (2007). Characterization and Control of Piscicosin CS526 Resistance. Msc thesis, Hokkaido University, Sapporo.

Hirsch, A., Grinsted, E., Chapman, H. R., and Mattick, A. T. R. (1951). A note on the inhibition of an anaerobic spore former in Swiss-type cheese by a nisin-producing Streptococcus. J. Dairy Res. 18, 205-206. doi: 10.1017/ s0022029900006075

Holcapkova, P., Raskova, K. Z., Hrabalikova, M., Salakova, A., Drbohlav, J., and Sedlarik, V. (2017). Isolation and thermal stabilization of bacteriocin nisin derived from whey for antimicrobial modifications of polymers. Int. J. Polym. Sci. 2017:3072582.

Holder, I. A., and Boyce, S. T. (1994). Agar well diffusion assay testing of bacterial susceptibility to various antimicrobials in concentration non toxic to human cells in culture. Burns 20, 426-429. doi: 10.1016/0305-4179(94)90035-3

Hsu, S. T., Breukink, E., Tischenko, E., Lutters, M. A., de Kruijff, B., Kaptein, R., et al. (2004). The nisin-lipid II complex reveals a pyrophosphate cage that provides a blueprint for novel antibiotics. Nat. Struct. Mol. Biol. 11, 963-967. doi: $10.1038 / \mathrm{nsmb} 830$

Jack, R. W., Tagg, J. R., and Ray, B. (1995). Bacteriocins of gram positive bacteria. Microbiol. Rev. 59, 171-200.

Jung, D., Bodyfelt, F., and Daeschel, M. (1992). Influence of fat emulsifiers on the efficacy of nisin in inhibiting Listeria monocytogenes in fluid milk. J. Dairy Sci. 75, 387-393. doi: 10.3168/jds.s0022-0302(92)77773-x

Kalchayanand, N. (1990). Extension of Shelf-Life of Vacuum-Packaged Refrigerated Fresh Beef by Bacteriocins of Lactic Acid Bacteria. Ph.D. thesis, University of Wyoming, Laramie, WY.

Katla, T., Møretrø, T., Aasen, I. M., Holck, A., Axelsson, L., and Naterstad, K. (2001). Inhibition of Listeria monocytogenes in cold smoked salmon by addition of sakacin P and/or live Lactobacillus sakei cultures. Food Microbiol. 18, 431-439. doi: 10.1016/j.ijfoodmicro.2009.04.004

Katla, T., Møretrø, T., Sveen, I., Aasen, I. M., Axelsson, L., Rorvik, L. M., et al. (2002). Inhibition of Listeria monocytogenes in chicken cold cuts by addition of sakacin P and sakacin P-producing Lactobacillus sakei. J. Appl. Microbiol. 93, 191-196. doi: 10.1046/j.1365-2672.2002.01675.x

Kato, T., Inuzuka, L., Kondo, M., and Matsuda, T. (2001). Growth of nisinproducing lactococci in cooked rice supplemented with soybean extract and its application to inhibition of Bacillus subtilis in rice miso. Biosci. Biotechnol. Biochem. 65, 330-337. doi: 10.1271/bbb.65.330

Kimara, H., Sashihara, T., Mastusaki, H., Sonomoto, K., and Izhizaki, A. (1998). Novel bacteriocin of Pediococcus sp. ISK-1 isolated from well-aged bed of fermented rice bran. Ann. N. Y. Acad. Sci. 864, 345-348. doi: 10.1111/j.17496632.1998.tb10336.x

Knight, K. P., Bartlett, F. M., McKellar, R. C., and Harris, L. J. (1999). Nisin reduces the thermal resistance of Listeria monocytogenes Scott A in liquid whole egg. J. Food Prot. 62, 999-1003. doi: 10.4315/0362-028x-62.9.999

Komitopoulou, E., Boziaris, I. S., Davies, E. A., Delves-Broughton, J., and Adams, M. R. (1999). Alicyclobacillus acidoterrestris in fruit juices and its control by nisin. Int. J. Food Sci. Technol. 34, 81-85. doi: 10.1046/j.1365-2621.1999. 00243.x

Lauková, A., and Czikková, S. (1999). The use of enterocin CCM 4231 in soy milk to control the growth of Listeria monocytogenes and Staphylococcus aureus. J. Appl. Microbiol. 87, 182-186.

Lauková, A., Czikková, S., and Burdová, O. (1999a). Anti-staphylococcal effect of enterocin in Sunar and yogurt. Folia Microbiol. 44, 707-711. doi: 10.1007/ bf02825667

Lauková, A., Czikková, S., Dobránsky, T., and Burdová, O. (1999b). Inhibition of Listeria monocytogenes and Staphylococcus aureus by enterocin CCM4231 in milk products. Food Microbiol. 16, 93-99.

Lauková, A., Vlaemynck, G., and Czikková, S. (2001). Effect of enterocin CCM 4231 on Listeria monocytogenes in Saint-Paulin cheese. Folia Microbiol. 46, 157-160. doi: 10.1007/bf02873596

Leroy, F., Foulquié Moreno, M. R., and De Vuyst, L. (2003). Enterococcus faecium RZS C5, an interesting bacteriocin producer to be used as a co-culture in food fermentation. Int. J. Food Microbiol. 88, 235-240. doi: 10.1016/s0168-1605(03) 00185-5

Leverentz, B., Conway, W. S., Camp, M. J., Janisiewicz, W. J., Abuladze, T., Yang, M., et al. (2003). Biocontrol of Listeria monocytogenes on fresh-cut produce by treatment with lytic bacteriophages and a bacteriocin. Appl. Environ. Microbiol. 69, 4519-4526. doi: 10.1128/aem.69.8.4519-4526.2003

Liao, C. H. S., and Fett, W. F. (2001). Analysis of native microflora and selection of strains antagonistic to human pathogens on fresh produce. J. Food Prot. 64, 1110-1115. doi: $10.4315 / 0362-028 x-64.8 .1110$

Lindström, M., Kiviniemi, K., and Korkeala, H. (2006). Hazard and control of group II (non-proteolytic) Clostridium botulinum in modern food processing. Int. J. Food Microbiol. 108, 92-104. doi: 10.1016/j.ijfoodmicro.2005.11.003

Liu, L., O'Conner, P., Cotter, P. D., Hill, C., and Ross, R. P. (2008). Controlling Listeria monocytogenes in cottage cheese through heterologous production of enterocin A by Lactococcus lactis. J. Appl. Microbiol. 104, 1059-1066. doi: 10.1111/j.1365-2672.2007.03640.x

Lyon, W. J., Sethi, J. K., and Glatz, B. A. (1993). Inhibition of psychrotrophic organisms by propionicin PLG-1, a bacteriocin produced by Propionibacterium thoenii. J. Dairy Sci. 76, 1506-1513. doi: 10.3168/jds.s0022-0302(93)77482-2

Margaret, A. R., and David, M. G. (1999). The ecological role of bacteriocins in bacterial competition. Trends Microbiol. Rev. 7, 129-133. doi: 10.1016/s0966$842 \times(99) 01459-6$

Martinez, B., Bravo, D., and Rodriguez, A. (2005). Consequences of the development of nisin-resistant Listeria monocytogenes in fermented dairy products. J. Food Prot. 68, 2383-2388. doi: 10.4315/0362-028x-68.11.2383

McAuliffe, O., Hill, C., and Ross, R. P. (1999). Inhibition of Listeria monocytogenes in cottage cheese manufactured with lacticin 3147 producing starter culture. J. Appl. Microbiol. 86, 251-256. doi: 10.1046/j.1365-2672.1999.00663.x

Mesa-Pereira, B., Rea, M. C., Cotter, P. D., Hill, C., and Ross, R. P. (2018). Heterologous expression of biopreservative bacteriocins with a view to low cost production. Front. Microbiol. 9:1654. doi: 10.3389/fmicb.2018.01654

Michael, L. C., Weeks, R., Drider, D., Vladimir, A. C., and Leon, M. T. D. (2018) Functions and emerging applications of bacteriocins. Curr. Opin. Biotechnol. 49, 23-28. doi: 10.1016/j.copbio.2017.07.011

Morgan, S. M., Garvin, M., Kelly, J., Ross, R. P., and Hill, C. (1999). Development of a lacticin 3147-enriched whey powder with inhibitory activity against food 
borne pathogens. J. Food Prot. 62, 1011-1016. doi: 10.4315/0362-028x-62.9. 1011

Morgan, S. M., Garvin, M., Ross, R. P., and Hill, C. (2001). Evaluation of a spray-dried lacticin 3147 powder for the control of Listeria monocytogenes and Bacillus cereus in a range of food systems. Lett. Appl. Microbiol. 33, 387-391. doi: 10.1046/j.1472-765x.2001.01016.x

Mossel, D. A. A., Corry, J. E. L., Struijk, C. B., and Baird, R. M. (1995). Essentials of the Microbiology of Foods: a Textbook for Advanced Studies. Hoboken, NJ: Wiley, 175-214.

Motlagh, A. M., Holla, S., Johnson, M. C., Ray, B., and Field, R. A. (1992). Inhibition of Listeria spp. in sterile food systems by pediocin $\mathrm{AcH}$, a bacteriocin produced by Pediococcus acidilactici H. J. Food Prot. 55, 337-343. doi: 10.4315/0362028X-55.5.337

Muriana, P. M. (1996). Bacteriocins for control of Listeria spp. in food. J. Food Prot. 59, S54-S63. doi: 10.4315/0362-028X-59.13.54

Nattress, F. M., and Baker, L. P. (2003). Effects of treatment with lysozyme and nisin on the microflora and sensory properties of commercial pork. Int. J. Food Microbiol. 85, 259-267. doi: 10.1016/s0168-1605(02)00545-7

Nattress, F. M., Yost, C. K., and Baker, L. P. (2001). Evaluation of the ability of lysozyme and nisin to control meat spoilage bacteria. Int. J. Food Microbiol. 70, 111-119. doi: 10.1016/s0168-1605(01)00531-1

Nel, H. A., Bauer, R., Wolfaardt, G. M., and Dicks, L. M. T. (2002). Effect of bacteriocins pediocin PD-1, plantaricin 423 and nisin on biofilms of Oenococcus oeni on a stainless steel surface. Am. J. Enol. Vitic. 53, 191-196.

Nielsen, J. W., Dickson, J. S., and Crouse, J. D. (1990). Use of a bacteriocin produced by Pediococcus acidilactici to inhibit Listeria monocytogenes associated with fresh meat. Appl. Environ. Microbiol. 56, 2142-2145.

Nieto-Lozano, J. C., Reguera-Useros, J. I., Peláez-Martínez, M. C., and Hardisson de la Torre, A. (2006). Effect of a bacteriocin produced by Pediococcus acidilactici against Listeria monocytogenes and Clostridium perfringens on Spanish raw meat. Meat Sci. 72, 57-61. doi: 10.1016/j.meatsci.2005.06.004

Nilsson, L., Huss, H. H., and Gram, L. (1997). Inhibition of Listeria monocytogenes on cold-smoked salmon by nisin and carbon dioxide atmosphere. Int. J. Food Microbiol. 38, 217-227. doi: 10.1016/s0168-1605(97)00111-6

Nissen, H., Holo, H., Axelsson, L., and Blom, H. (2001). Characterization and growth of Bacillus spp. in heat-treated cream with and without nisin. J. Appl. Microbiol. 90, 530-534. doi: 10.1046/j.1365-2672.2001.01279.x

Okeley, N. M., Paul, M., Stasser, J. P., Blackburn, N., and van der Donk, W. A. (2003). SpaC and $\mathrm{NisC}$, the cyclases involved in subtilin and nisin biosynthesis, are zinc proteins. Biochemistry 42, 13613-13624. doi: 10.1021/bi035 4942

Okuda, K., Takeshi, Z., Shinya, S., Tadayuki, I., Akiko, T., Satomi, Y., et al. (2013). Effects of bacteriocins on methicillin-resistant Staphylococcus aureus biofilm. Antimicrob. Agents Chemother. 57, 5572-5579. doi: 10.1128/AAC.00888-13

O’Mahony, T., Rekhif, N., Cavadini, C., and Fitzgerald, G. F. (2001). The application of a fermented food ingredient containing 'variacin', a novel antimicrobial produced by Kocuria varians, to control the growth of Bacillus cereus in chilled dairy products. J. Appl. Microbiol. 90, 106-114. doi: 10.1046/j. 1365-2672.2001.01222.x

O'Sullivan, L., O'Connor, E. B., Ross, R. P., and Hill, C. (2006). Evaluation of live-culture-producing lacticin 3147 as a treatment for the control of Listeria monocytogenes on the surface of smear-ripened cheese. J. Appl. Microbiol. 100, 135-143. doi: 10.1111/j.1365-2672.2005.02747.x

Parente, E., and Hill, C. (1992). Inhibition of Listeria in buffer, broth, and milk by enterocin 1146, a bacteriocin produced by Enterococcus faecium. J. Food Prot. 55, 503-508. doi: 10.4315/0362-028X-55.7.503

Penney, V., Henderson, G., Blum, C., and Johnson-Green, P. (2004). The potential of phytopreservatives and nisin to control microbial spoilage of minimally processed fruit yogurts. Int. Food Sci. Emerg. Technol. 5, 369-375. doi: 10.1016/ j.ifset.2003.10.006

Ponce, E., Pla, R., Sendra, E., Guamis, B., and Mor-Mur, M. (1998). Combined effect of nisin and high hydrostatic pressure on destruction of Listeria innocua and Escherichia coli in liquid whole egg. Int. J. Food Microbiol. 43, 15-19. doi: 10.1016/s0168-1605(98)00088-9

Pucci, M. J., Vedamutthu, E. R., Kunka, B. S., and Vendenbergh, P. A. (1988). Inhibition of Listeria monocytogenes by using bacteriocin PA-1 produced by Paediococcus acidilactici PAC 1.0. Appl. Environ. Mixrobiol. 54, 2349-2353.
Rea, M. C., Rea, M. C., Sit, C. S., Clayton, E., O’Connor, P. M., Whittal, R. M., et al. (2010). Thuricin CD, a posttranslationally modified bacteriocin with a narrow spectrum of activity against Clostridium difficile. Proc. Natl. Acad. Sci. U.S.A. 107, 9352-9357. doi: 10.1073/pnas.0913554107

Rilla, N., Martínez, B., Delgado, T., and Rodríguez, A. (2003). Inhibition of Clostridium tyrobutyricum in Vidiago cheese by Lactococcus lactis ssp. lactis IPLA 729, a nisin Z producer. Int. J. Food Microbiol. 85, 23-33. doi: 10.1016/ s0168-1605(02)00478-6

Rodríguez, E., Calzada, J., Arqués, J. L., Rodríguez, J. M., Núñez, M., and Medina, M. (2005). Antimicrobial activity of pediocin-producing Lactococcus lactis on Listeria monocytogenes, Staphylococcus aureus and Escherichia coli O157:H7 in cheese. Int. Dairy J. 15, 51-57. doi: 10.1016/j.idairyj.2004.05.004

Rodríguez, J. M., Martinez, M. I., and Kok, J. (2002). Pediocin PA-1, a widespectrum bacteriocin from lactic acid bacteria. Crit. Rev. Food Sci. Nutr. 42, 91-121. doi: 10.1080/10408690290825475

Rosas, C. J., and Escartin, E. F. (2000). Survival and growth of Vibrio cholerae O1, Salmonella typhi and Escherichia coli O157:H7 in alfalfa sprouts. J. Food Sci. 65, 162-165. doi: 10.1111/j.1365-2621.2000.tb15973.x

Rosenberg, A. H., Lade, B. N., Chui, D., Lin, S., Dunn, J. J., and Studier, F. W. (1987). Vectors for selective expression of cloned DNAs by T7 RNA polymerase. Gene 56, 125-135. doi: 10.1016/0378-1119(87)90165-x

Rosenquist, H., and Hansen, A. (1998). The antimicrobial effect of organic acids, sour dough and nisin against Bacillus subtilis and B. licheniformis isolated from wheat bread. J. Appl. Microbiol. 85, 621-631. doi: 10.1046/j.1365-2672.1998. 853540.x

Ross, R. P., Galvin, M., McAuliffe, O., Morgan, S., Ryan, M., Twomey, D. P., et al. (1999). Developing applications for lactococcal bacteriocins. Antonie van Leeuwenhoek 76, 337-346. doi: 10.1007/978-94-017-2027-4_18

Ross, R. P., Stanton, C., Hill, C., Fitzgerald, G. F., and Coffey, A. (2000). Novel cultures for cheese improvement. Trends Food Sci. Technol. 11, 96-104. doi: 10.1016/s0924-2244(00)00057-1

Ryan, M. P., Rea, M. C., Hill, C., and Ross, R. P. (1996). An application in cheddar cheese manufacture for a strain of Lactococcus lactis producing a novel broad-spectrum bacteriocin, lacticin 3147. Appl. Environ. Microbiol. 62, 612-619.

Ryan, M. P., Ross, R. P., and Hill, C. (2001). Strategy for manipulation of cheese flora using combinations of lacticin 3147-producing and -resistant cultures. Appl. Environ. Microbiol. 67, 2699-2704. doi: 10.1128/aem.67.6.2699-2704. 2001

Sashihara, T., Hirokazu, K., Kimura, T., Higuchi, A. A., Hiromi, M., and Kenji, S. (2000). A novel lantibiotic, nukacin ISK-1, of Staphylococcus warneri ISK1: cloning of the structural gene and identification of the structure. Biosci. Biotechnol. Biochem. 64, 2420-2428. doi: 10.1271/bbb.64.2420

Scannell, A. G. M., Hill, C., Ross, R. P., Marx, S., Hartmeier, W., and Arendt, E. K. (2000). Development of bioactive food packaging materials using immobilised bacteriocins lacticin 3147 and Nisaplin. Int. J. Food Microbiol. 60, 241-249. doi: 10.1016/s0168-1605(00)00314-7

Scannell, A. G. M., Schwarz, G., Hill, C., Ross, R. P., and Arendt, E. K. (2001). Preinoculation enrichment procedure enhances the performance of bacteriocinogenic Lactococcus lactis meat starter culture. Int. J. Food Microbiol. 64, 151-159. doi: 10.1016/s0168-1605(00)00455-4

Schlyter, J. H., Glass, K. A., Loeffelholz, J., Degnan, A. J., and Luchansky, J. B. (1993). The effects of diacetate with nitrite, lactate, or pediocin on the viability of Listeria monocytogenes in turkey slurries. Int. J. Food Microbiol. 19, 271-281. doi: 10.1016/0168-1605(93)90019-d

Schöbitz, R., Zaror, T., León, O., and Costa, M. (1999). A bacteriocin from Carnobacterium piscicola for the control of Listeria monocytogenes in vacuumpackaged meat. Food Microbiol. 16, 249-255. doi: 10.1006/fmic.1998.0241

Schuman, J. D., and Sheldon, B. W. (2003). Inhibition of Listeria monocytogenes in $\mathrm{pH}$-adjusted pasteurized liquid whole egg. J. Food Prot. 66, 999-1006. doi: 10.4315/0362-028x-66.6.999

Shilja, C., Dhanshree, L., Bettadaiah, B. K., and Rajagopal, K. (2015). Assessing the antimicrobial activites of Ocins. Front. Microbiol. 6:1034. doi: 10.3389/fmicb. 2015.01034

Stohr, V., Joffraud, J. J., Cardinal, M., and Leroi, F. (2001). Spoilage potential and sensory profile associated with bacteria isolated from cold-smoked salmon. Food Res. Int. 34, 797-806. doi: 10.1016/s0963-9969(01)00101-6 
Strasser de Saad, A. M., Pasteris, S. E., and Manca de Nadra, M. C. (1995). Production and stability of pediocin N5p in grape juice medium. J. Appl. Bacteriol. 78, 473-476. doi: 10.1111/j.1365-2672.1995.tb03087.x

Studier, F. W., and Moffatt, B. A. (1986). Use of bacteriophage T7 RNA polymerase to direct selective high-level expression of cloned genes. J. Mol. Biol. 189, 113-130. doi: 10.1016/0022-2836(86)90385-2

Studier, F. W., Rosenberg, A. H., Dunn, J. J., and Dubendorff, J. W. (1990). Use of T7 RNA polymerase to direct expression of cloned genes. Methods Enzymol. 185, 60-89. doi: 10.1016/0076-6879(90)85008-c

Taalat, E., Yousef, A. E., and Ockerman, H. W. (1993). Inactivation and attachment of Listeria monocytogenes on beef muscle treated with lactic acid and selected bacteriocins. J. Food Prot. 56, 29-33. doi: 10.4315/0362-028X-56.1.29

Taormina, P. J., Beuchat, L. R., and Slutsker, L. (1999). Infections associated with eating seed sprouts: an international concern. Emerg. Infect. Dis. 5, 626-634. doi: 10.3201/eid0505.990503

Thévenot, D., Dernburg, A., and Vernozy-Rozand, C. (2006). An updated review of Listeria monocytogenes in the pork meat industry and its products. J. Appl. Microbiol. 101, 7-17. doi: 10.1111/j.1365-2672.2006.02962.x

Thomas, L. V., Clarkson, M. R., and Delves-Broughton, J. (2000). "Nisin," in Natural Food Antimicrobial Systems, ed. A. S. Naidu (Boca Raton, FL: CRC Press), 463-524.

Thomas, L. V., Ingram, R. E., Bevis, H. E., Davies, E. A., Milne, C. F., and DelvesBroughton, J. (2002). Effective use of nisin to control Bacillus and Clostridium spoilage of a pasteurized mashed potato product. J. Food Prot. 65, 1580-1585. doi: 10.4315/0362-028x-65.10.1580

Torri Tarelli, G., Carminati, D., and Giraffa, G. (1994). Production of bacteriocins active against Listeria monocytogenes and Listeria innocua from dairy enterococci. Food Microbiol. 11, 243-252. doi: 10.1006/fmic.1994.1027

Tsakalidou, E., Zoidou, E., Pot, B., Wassill, L., Ludwig, W., Devriese, L. A., et al. (1998). Identification of streptococci from Greek Kasseri cheese and description of Streptococcus macedonicus sp. nov. Int. J. Syst. Bacteriol. 48, 519-527. doi: 10.1099/00207713-48-2-519

Urso, R., Rantsiou, K., Cantoni, C., Comi, G., and Cocolin, L. (2006). Technological characterization of a bacteriocin-producing Lactobacillus sakei and its use in fermented sausages production. Int. J. Food Microbiol. 110, 232-239. doi: 10.1016/j.ijfoodmicro.2006.04.015

Van Heusden, H. E., de Kruijff, B., and Breukink, E. (2002). Lipid II induces a transmembrane orientation of the pore-forming peptide lantibiotic nisin. Biochemistry 41, 12171-12178. doi: 10.1021/bi026090x

Vaughan, A., Eijsink, V. J., O’Sullivan, T. F., O’Hanlon, K., and van Sinderen, D. (2001). An analysis of bacteriocins produced by lactic acid bacteria isolated from malted barley. J. Appl. Microbiol. 91, 131-138. doi: 10.1046/j.1365-2672. 2001.01365.x

Vescovo, M., Torriani, S., Orsi, C., Macciarolo, F., and Scolari, G. (1996). Application of antimicrobial-producing lactic acid bacteria to control pathogens in ready-to-use vegetables. J. Appl. Microbiol. 81, 113-119. doi: 10.1111/j.1365-2672.1996.tb04487.x

Vignolo, G., Fadda, S., de Kairuz, M. N., Holgado, A. P. R., and Oliver, O. (1998). Effects of curing additives on the control of Listeria monocytogenes by lactocin 705 in meat slurry. Food Microbiol. 15, 259-264. doi: 10.1006/fmic.1997. 0166

Vignolo, G., Palacios, J., Farias, M. E., Sesma, F., Schillinger, U., Holzapfel, W., et al. (2000). Combined effect of bacteriocins on the survival of various Listeria species in broth and meat system. Curr. Microbiol. 41, 410-416. doi: 10.1007/ s002840010159

Villani, F., Salzano, G., Sorrentino, E., Pepe, O., Marino, P., and Coppola, S. (1993). Enterocin 226 NWC, a bacteriocin produced by Enterococcus faecalis 226, active against Listeria monocytogenes. J. Appl. Bacteriol. 74, 380-387. doi: 10.1111/j. 1365-2672.1993.tb05142.x

Wiedemann, I., Benz, R., and Sahl, H.-G. (2004). Lipid II-mediated pore formation by the peptide antibiotic nisin: a black lipid membrane study. J. Bacteriol. 186, 3259-3261. doi: 10.1128/jb.186.10.3259-3261. 2004

Wiedemann, I., Breukink, E., van Kraaij, C., Kuipers, O. P., Bierbaum, G., de Kruijff, B., et al. (2001). Specific binding of nisin to the peptidoglycan precursor lipid II combines pore formation and inhibition of cell wall biosynthesis for potent antibiotic activity. J. Biol. Chem. 276, 1772-1779. doi: 10.1074/jbc. m006770200

Wilderdyke, M. R., Smith, D. A., and Brashears, M. M. (2004). Isolation, identification, and selection of lactic acid bacteria from alfalfa sprouts for competitive inhibition of foodborne pathogens. J. Food Prot. 67, 947-951. doi: 10.4315/0362-028x-67.5.947

Yamazaki, K., Murami, M., Kawai, Y., Inoue, N., and Matsuda, T. (2000). Use of nisin for inhibition of Alicyclobacillus acidoterrestris in acidic drinks. Food Microbiol. 17, 315-320. doi: 10.1006/fmic.1999.0309

Yang, S. C., Lin, C. H., Sung, C. T., and Fang, J. Y. (2014). Antibacterial activities of bacteriocins: application in foods and pharmaceuticals. Front. Microbiol. 5:241. doi: $10.3389 /$ fmicb.2014.00241

Conflict of Interest Statement: The authors declare that the research was conducted in the absence of any commercial or financial relationships that could be construed as a potential conflict of interest.

Copyright (c) 2019 Choyam, Srivastava, Shin and Kammara. This is an open-access article distributed under the terms of the Creative Commons Attribution License (CC BY). The use, distribution or reproduction in other forums is permitted, provided the original author(s) and the copyright owner(s) are credited and that the original publication in this journal is cited, in accordance with accepted academic practice. No use, distribution or reproduction is permitted which does not comply with these terms. 